\title{
Anatomical Characters of Leave and Stem of Calea serrata Less., Asteraceae
}

\author{
Júlia Gabriela Camilotti ${ }^{1}$, Ciane Costa Biu ${ }^{2}$, Paulo Vitor Farago ${ }^{1}$, Vera Lúcia Pereira dos \\ Santos $^{3}$, Celia Regina Cavichiolo Franco ${ }^{4}$ and Jane Manfron Budel ${ }^{*}$ \\ ${ }^{I}$ Departamento de Ciências Farmacêuticas; Universidade Estadual de Ponta Grossa; Ponta Grossa - PR - Brasil. \\ ${ }^{2}$ Departamento de Ciências Biológicas; Universidade Federal do Paraná; Curitiba - PR - Brasil. ${ }^{3}$ Departamento de \\ Engenharia, Saúde e Meio Ambiente; Centro Universitário Internacional Uninter; Curitiba - Paraná - Brasil. \\ ${ }^{4}$ Departamento de Biologia Celular; Universidade Federal do Paraná; Curitiba - Paraná - Brasil
}

\begin{abstract}
The genus Calea belongs to the tribe Heliantheae and presents about 125 species. Calea serrata, popularly known as erva-de-cobra, chá-amargo and quebra-tudo, is an endemic species found in southern Brazil and is used in traditional medicine to treat ulcers and livers problems. The present work aimed to study the pharmacobotanical characters of leaves and stems of C. serrata for quality control purposes. The plant material was processed according to standard methods of light and scanning electron microscopy. Glandular capitate-stalked and capitatesessile, uniseriate multicellular non-glandular trichome with tapered apical cell, conical non-glandular trichome, isobilateral mesophyll, secretory ducts near the endoderm and circular shape with six ribs in the stem were important characters, which contributed to the identification of the species.
\end{abstract}

Key words: Calea serrata, anatomical study, quality control

\section{INTRODUCTION}

The family Asteraceae, also known as Compositae, is considered one of the largest among the Angiosperms. It presents about 1100 genera and approximately 25000 species, which have been highlighted by great therapeutic potential (Bremer 1994). The genus Calea L. belongs to the tribe Heliantheae and presents about 125 species that inhabit in tropical and subtropical regions of the New World, and 85 of them are found in Brazil, mainly in the states of Distrito Federal, Bahia, Minas Gerais, Rio de Janeiro, São Paulo and Paraná. Representatives of Calea are often mistaken with the species of Aspilia and Wedelia (Roque and Carvalho 2011).
Calea species has been chemically studied for the isolation and characterization of compounds, such as Calea uniflora Less. (Nascimento et al. 2002; Nascimento et al. 2004), C. clematidea Baker (Flach et al. 2002), C. urticifolia (Mill.) DC. (Yamada et al. 2004) and C. zacatechichi Schltdl. (Wu et al. 2011). Pharmacological activities have been demonstrated for the species of the genus, such as antispasmodic (Kohler et al. 2002), antifungal (Flach et al. 2002), anti-hypertensive (Guerrero et al. 2002), trypanocidal (Nascimento et al. 2002; Nascimento et al. 2004), cytotoxic (Nakagawa et al. 2005) and leishmanicidal (Wu et al. 2011).

Calea serrata, popularly known as erva-de-cobra, chá-amargo and quebra-tudo, is an endemic species found in Southern Brazil (Ribeiro et al.

*Author for correspondence: janemanfron@hotmail.com 
2008). It is a woody vine that presents simple, opposite, and serrated margin leaves and ligulate and yellowish flowers. It is used in traditional medicine to treat the ulcers and liver problems. Pharmacological studies have shown acaricidal activities (Ribeiro et al. 2008; Ribeiro et al. 2011) and inhibition of acetylcholinesterase (Ribeiro et al. 2012).

Morpho-anatomical studies were conducted with species of Calea. However, no work has been carried out to investigate the anatomical data of $C$. serrata in order to provide additional features for differentiating this species from other Calea. Thus, the present work aimed to study the anatomical characters of leaves and stems of $C$. serrata for quality control purposes.

\section{MATERIAL AND METHODS}

\section{Botanical material}

The plant material was collected at the Fazenda São Maximiano, located in the region of Serra do Sudoeste, in the city of Guaíba, state of Rio Grande do Sul, Brazil (coordinates $30^{\circ} 10^{\prime} \mathrm{S}$ and $51^{\circ} 20^{\prime} \mathrm{W}$, and $27 \mathrm{~m}$ high) in December 2010. The voucher was identified and its equivalent was registered under number ICN 51057 at the Herbário do Instituto de Ciências Naturais from Universidade Federal do Rio Grande do Sul.

\section{Morpho-anatomical Study}

Stems and leaves obtained $5 \mathrm{~cm}$ from the apex and adult leaves were collected from at least five specimens and fixed in FAA 70 (Johansen 1940), which was replaced by $70 \%$ ethanol (Berlyn and Miksche 1976). The material was either sectioned by hand or dehydrated, embedded in glycolmethacrylate (Leica historesin ${ }^{\circledR}$ ) and sectioned using the microtome Leica RM-2145. Transverse and longitudinal sections were stained with toluidine blue (O'Brien et al. 1965) or astra blue and basic fuchsine combination (Roeser 1962).

\section{Micro-chemical Tests}

The following standard solutions were employed for micro-chemical tests: hydrochloric phloroglucin to reveal lignin (Sass 1951), Sudan III for lipophilic compounds (Foster 1949), ferric chloride for phenolic substances (Johansen 1940), and iodine-iodide for starch (Berlyn and Miksche 1976). Photomicrographs were taken with the light microscope Olympus CX 31 coupled to the camera C7070.

\section{Scanning Electron Analysis (SEM)}

The fixed material was dehydrated in a graded ethanol series and by $\mathrm{CO}_{2}$ critical point apparatus Balzers CPD-030 and coated with gold by Balzers Sputtering SCD-030. Electron micrographs were taken with the scanning microscope Jeol JSM6360LV.

\section{RESULTS AND DISCUSSION}

The foliar blade of C. serrata Less. (Fig. 1A), in face view, showed sinuous shape in the epidermal cells and relatively thin anticlinal cell walls on both the sides (Figs. 1B, C). In cross-section, the epidermis was uniseriate and coated by a thin and smooth cuticle (Fig. 2B) on both the surfaces. The leaves of $C$. serrata were hypostomatic. The stomata were mainly anomocytic (Fig. 1B) or anisocytic and were located even or slightly above regarding the other epidermal cells.

Both non-glandular and glandular trichomes could occur singly and often were located in small epidermal depressions. There were two types of the glandular trichomes. One of them was capitatestalked with uniseriate stalk, which consisted of 34 cells. The other one was capitate-sessile (Fig. 1E). They were covered by a cuticle with dense cytoplasm. Considering micro-chemical tests the glandular trichomes reacted with Sudam III. There were two types of non-glandular trichomes. One of them was conical (Fig. 1D) and consisted of 6-8 cells. The other one was multicellular (Figs. 2A, C) uniseriate and composed by 5-6 cells at the base and tapered apical cell.

The leaves of $C$. serrata presented dorsiventral mesophyll and comprised palisade parenchyma composed by a layer beneath the epidermis. The spongy parenchyma showed 4-5 layers with some small intercellular spaces (Figs. 2C, D). Collateral vascular bundles were embedded in the chlorenchyma and were surrounded by the endodermal cells with visible Casparian strips. Near the endoderm, secretory ducts could occur, lined with a uniseriate epithelium whose 4-6 cells released a lipophilic product. The midrib transection had biconvex shape. Below the uniseriate epidermis, there was the angular collenchyma composed by 1-2 rows. A single collateral vascular bundle occurred in the ground parenchyma. Secretory ducts had the same characteristics previously described. 
In cross-section, the petiole was concave adaxially and convex abaxially. The angular collenchyma comprised 1-2 layers. Vascular system was formed by three free vascular bundles in open arc with lateral rib traces (Fig 2E). Secretory ducts as reported for leaf blade were observed next to the endoderm (Fig. 2G). Starch grains were observed in the fundamental parenchyma (Fig. 2F).

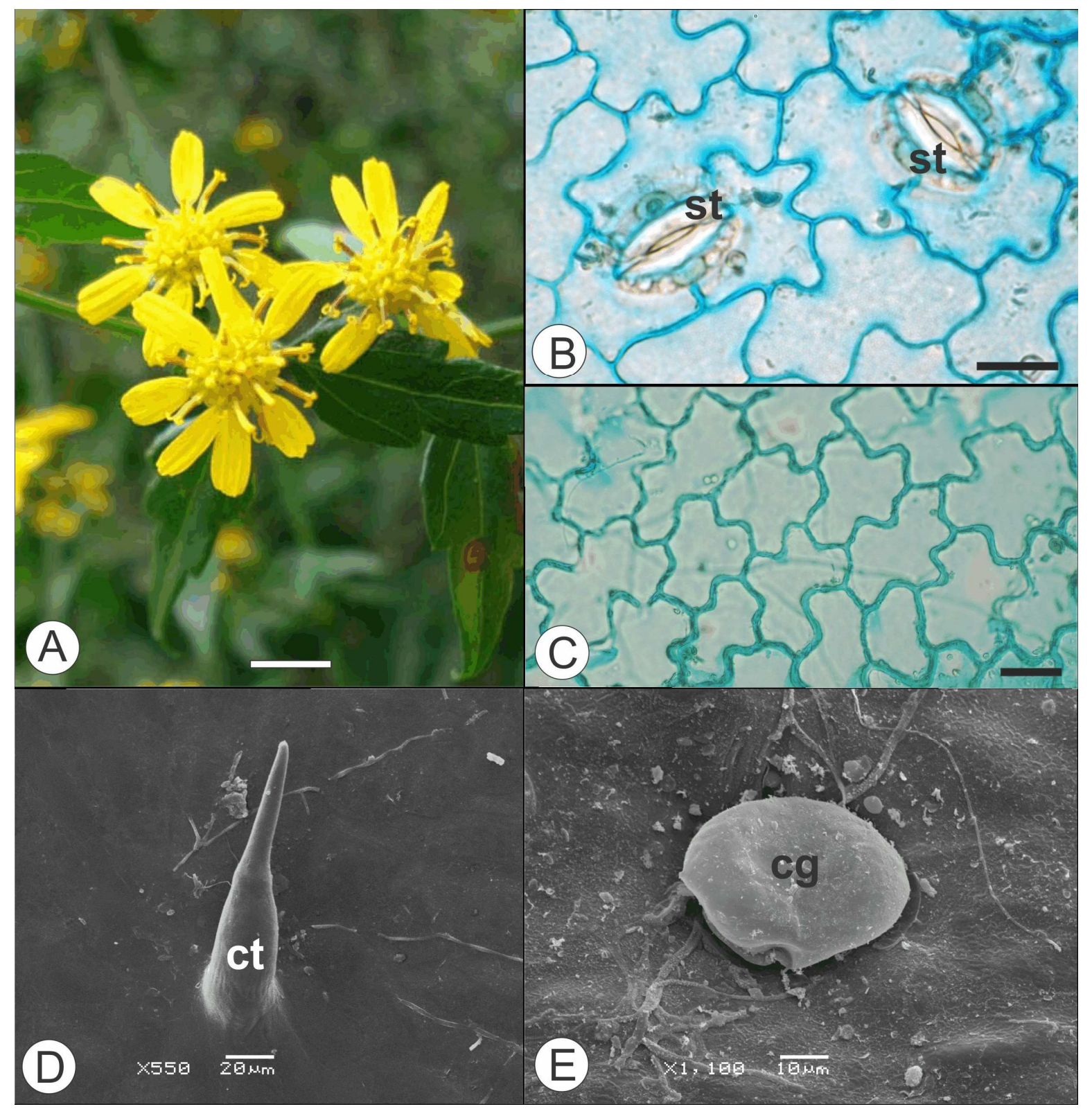

Figure 1 - Calea serrata Less., Asteraceae. A. Aspect of aerial vegetative and reproductive organs. B. Abaxial side of the epidermis, in surface view, revealing anticlinal epidermal cell walls and stomata (st). C. Adaxial side of the epidermis, in surface view, showing anticlinal epidermal cell walls. D. Conical non-glandular trichome (ct), in surface view. E. Capitatesessile glandular trichome (ct). Bar $=2 \mathrm{~cm}(\mathrm{~A}) ; 20 \mu \mathrm{m}(\mathrm{B}, \mathrm{C})$. 


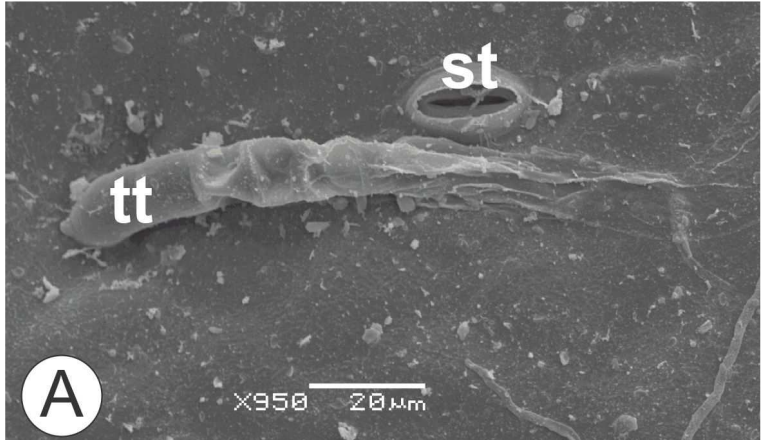

CU
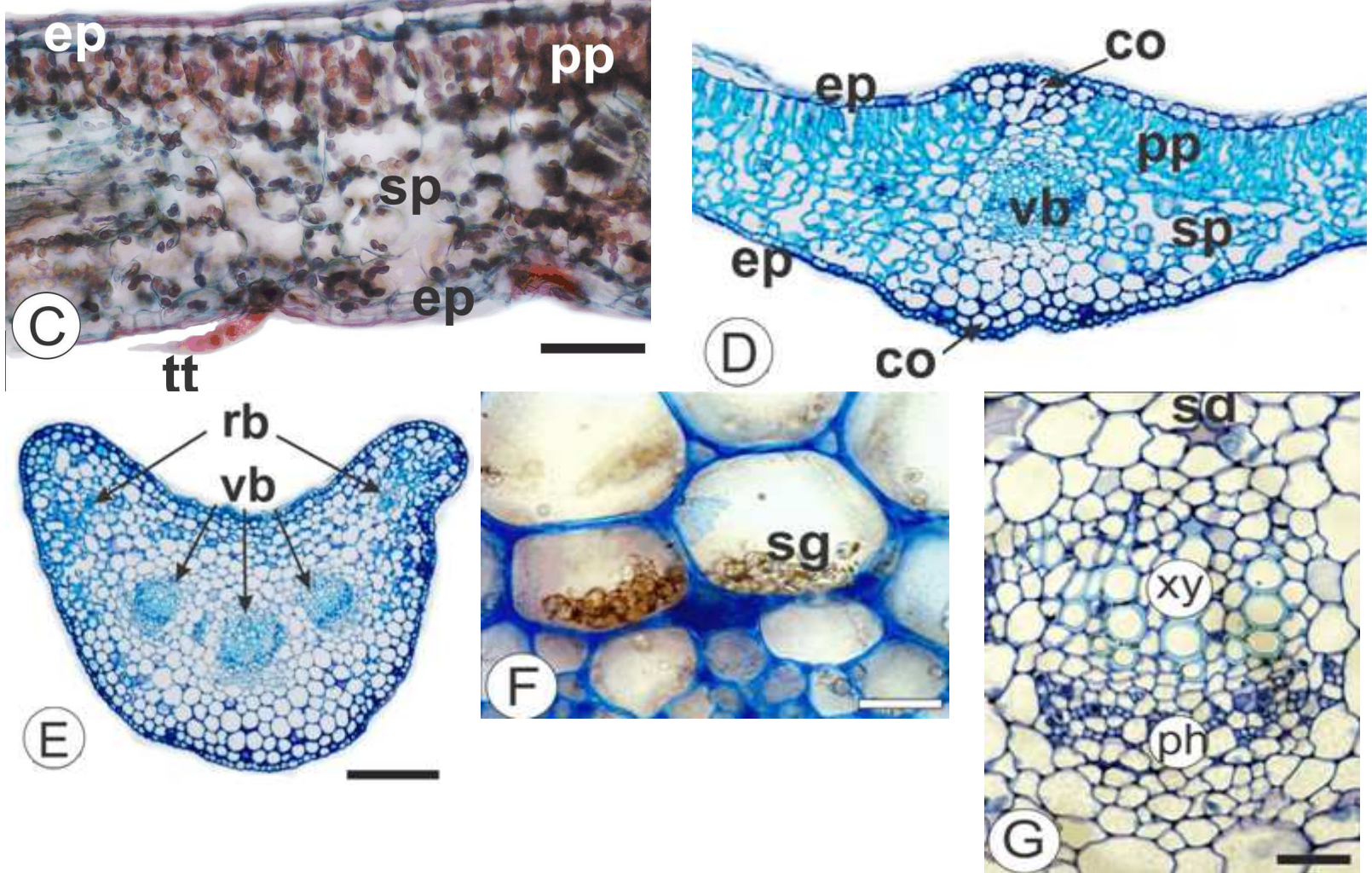

Figure 2 - Calea serrata Less., Asteraceae - Leaves. A. Abaxial epidermis in surface view, exhibiting stomata (st) and non-glandular trichome with tapered apical cell (tt). B. Cross-section of the blade showing capitate-sessile glandular trichome (cg) and cuticle (cu). C. Blade organization, in transection, revealing dorsiventral mesophyll, uniseriate epidermis (ep), cuticle, non-glandular trichome with tapered apical cell, palisade parenchyma (pp), and spongy parenchyma (sp). D. Midrib, showing vascular bundle (vb) in the center, epidermis, collenchyma (co), palisade and spongy parenchyma. E. Petiole, in cross-section, indicating three free vascular bundles in open arc with rib bundles (rb). F. Detail of the starch grains (sg) in the fundamental parenchyma of the petiole. G. Detail of the collateral vascular bundle, in the petiole, indicating phloem (ph), xylem (xy) and secretory duct (sd). Bar $=20$ $\mu \mathrm{m}(\mathrm{B}, \mathrm{G}, \mathrm{F}), 100 \mu \mathrm{m}(\mathrm{C}), 200 \mu \mathrm{m}$ (D, E).

The stem had circular shape with six ribs in transection (Fig. 3A). The caulinar epidermis was uniseriate and the cuticle was thin and smooth (Fig. 3C) and reacted positively to lipophilic compounds. Below the epidermis, the chlorenchyma was alternate with angular collenchyma, which had about 6-7 rows (Figs. 3B, C). Perivascular fiber caps were observed (Figs. 3B, D). The secretory ducts had the same features as previously described for the foliar blade. The 
endoderm (Fig. 3B) showed starch grains and encircled the cortex internally. The central region comprehended relatively large parenchymatic cells
(Fig. 3B). The vascular cylinder presented cambia forming phloem outward and xylem inward (Figs. $3 \mathrm{~B}, \mathrm{D}, \mathrm{E})$.

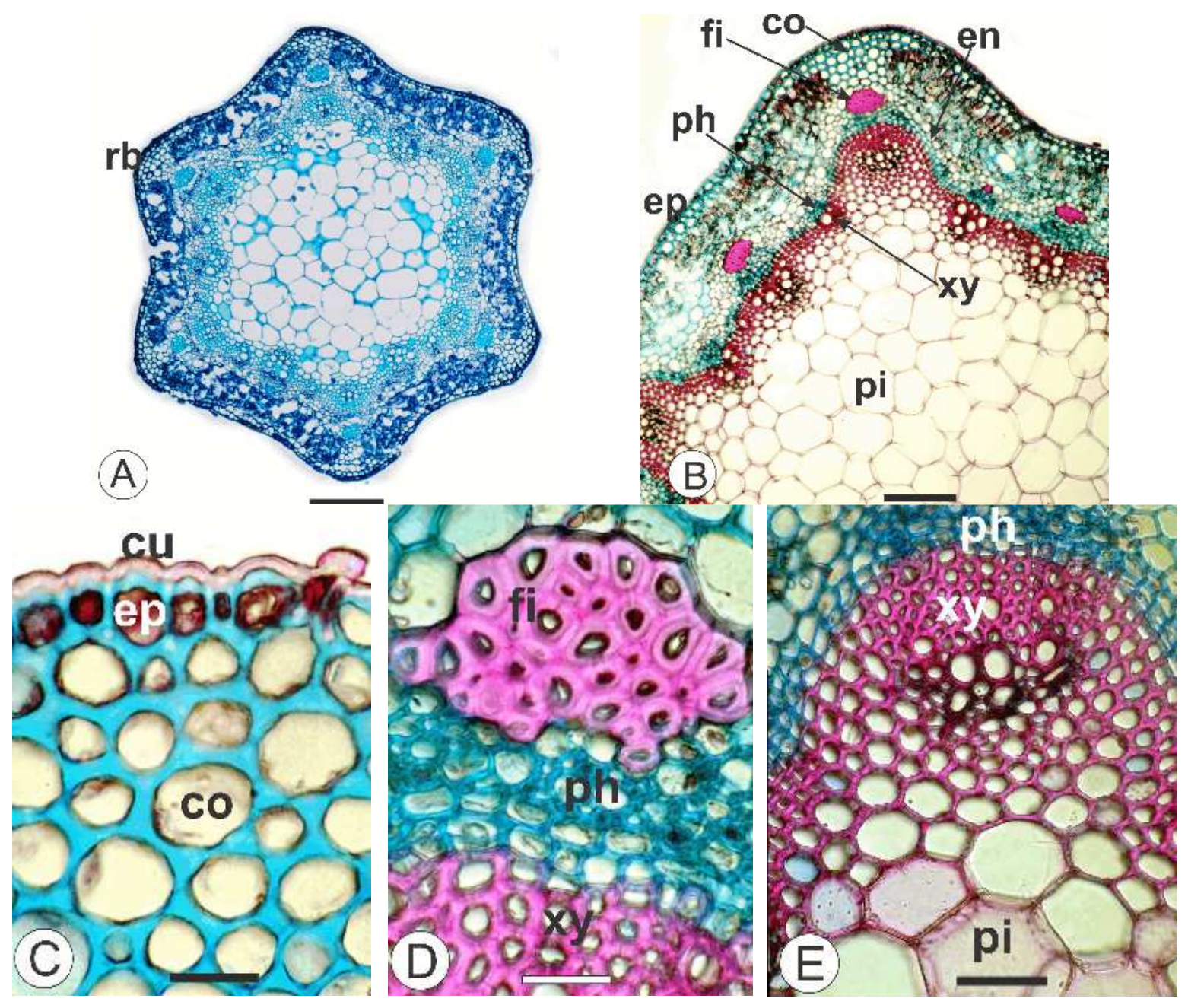

Figure 3 - Calea serrata Less., Asteraceae - Stem in cross-section - A. An overview of the stem exhibiting six ribs (rb). B. Stem, indicating fiber (fi), epidermis (ep), collenchyma (co), endoderm (en), phloem (ph), xylem (xy) and pith (pi). C. Detail of the epidermis, cuticle and collenchyma. D. Detail of the vascular cylinder and perivascular fiber cap. E. Detail of the vascular cylinder and pith. Bar $=200 \mu \mathrm{m}(\mathrm{A}), 100 \mu \mathrm{m}(\mathrm{B}), 20 \mu \mathrm{m}(\mathrm{C}, \mathrm{D}, \mathrm{E})$.

\section{DISCUSSION}

According to Metcalfe and Chalk (1950), the presence of stomata in frontal view has diagnostic value in Asteraceae. Several genera of Asteraceae can present anomocytic (predominantly) and anisocytic stomata as observed in Gochnatia (Youssef et al. 2013), Lucilia (Duarte et al. 2011), Baccharis (Oliveira et al. 2011; Souza et al. 2011), Mikania, Porophyllum and Vernonia (Milan et al. 2006). The studied species revealed both the anomocytic and anisocytic stomata only in the abaxial surface.

Cavities, idioblasts, ducts and glandular trichomes can be observed in leaves of many members of Asteraceae (Milan et al. 2006; Duarte et al. 2011; Budel et al. 2012; Budel et al. 2013). Trichome types are useful features in the quality control of herbal drug, mainly as powder or dried fragments. In this study, $C$. serrata showed glandular trichomes and secretory ducts. According to Werker (2000), there was no wholly appropriate 
classification for the trichomes. In this work, morphology was used as classification criteria. Glandular trichomes have been described for Asteraceae family (Milan et al. 2006; Souza et al. 2011; Youssef et al. 2013; Pereira et al. 2014). C. serrata showed two types of glandular trichomes, capitate-stalked and capitate-sessile.

C. serrata showed two types of non-glandular trichomes. One of them was multicellular uniseriate and composed by 5-6 cells at the base and tapered apical cell. The other one was conical and consisted of 6-8 cells. This type was common in Asteraceae family (Krak1 and Mráz 2008; Tavares et al. 2012).

Asteraceae typically exhibits a mesophyll differentiated into palisade and spongy parenchyma (Oliveira et al. 2011; Souza et al. 2011; Duarte et al. 2011; Souza et al. 2013). Calea serrata have shown an isobilateral arrangement for chlorenchyma.

Secretory ducts are frequently related to the endoderm or vascular system for different members of Asteraceae (Pagni and Masini 1999; Budel and Duarte 2010; Souza et al. 2011; Budel et al. 2012). The evaluated species exhibited secretory ducts near to the endoderm. The occurrence of glandular trichomes and secretory ducts supports additional studies to be undertaken correlated to the isolation and characterization of chemical compounds and further microbiological, pharmacological and toxicological studies for Calea species.

With reference to the caulinar microscopic characters, the stem showed remaining epidermis, strands of chlorenchyma alternating with collenchyma, endoderm limiting internally the cortex and vascular cambia forming phloem outward and xylem inward common features of Calea. Concerning the caulinar shape, in crosssection, $C$. serrata had circular shape with six ribs.

\section{CONCLUSIONS}

As expected, the features of leaves and stems of $C$. serrata agreed with the Calea genus. These characters should be evaluated as a whole to describe the species, even though the subsequent structures might be emphasized as distinguishing structures among the Calea genus: glandular capitate-stalked and capitate-sessile, uniseriate multicellular non-glandular trichome with tapered apical cell, conical non-glandular trichome, dorsiventral mesophyll, secretory ducts near the endoderm and circular shape with six ribs in the steam.

\section{ACKNOWLEDGMENTS}

The authors are thankful to Nelson Ivo Matzenbacher from ICN/UFRGS for the specie taxonomic identification and Figure $1 \mathrm{~A}$, and to CME/UFPR for the scanning electron micrographs.

\section{REFERENCES}

Berlyn GP, Miksche JP. Botanical microtechnique and cytochemistry. Eames: Iowa State University, 1976.

Bremer K. Asteraceae: cladistics and classification. Timber Press, Portland, Oregon, 1994; p 752.

Budel JM, Duarte MR. Macro and microscopic characters of the aerial vegetative organs of Carqueja: Baccharis usterii Heering. Braz Arch Biol Technol. 2010; 53(1): 123-31.

Budel JM, Duarte MR, Döll-Boscardin PM, Farago PV, Matzenbacher NI, Sartoratto A, et al. Composition of essential oils and secretory structures of Baccharis anomala, B. megapotamica and B. ochracea. J Essent Oil Res. 2012; 24: 19-24.

Budel JM, Farago PV, Duarte MR Pharmacobotanical study of Baccharis cognata DC. (Asteraceae: Astereae). Lat Am J Pharm. 2013; 32: 540-544.

Duarte MR, Budel JM, Matzenbacher NI. Microscopic Diagnosis of the Leaf and Stem of Lucilia nitens Less., Asteraceae. Lat Am J Pharm. 2011; 30(10): 2070-2075.

Flach A, Gregel A, Simionatto E, Silva UF, Zanatta N, Morel AF, et al. Chemical analysis and antifungal activity of the essential oil of Calea clematidea. Planta Med. 2002; 68(9): 836-838.

Foster AS. Practical plant anatomy. 2. ed. Princeton: D. Van Nostrand, 1949.

Guerrero MF, Puebla P, Carrón R, Martín ML, Arteaga L, Román S. Assessment of the anti-hypertensive and vasodilator effects of ethanolic extracts of some Colombian medicinal plants. $J$ Ethnopharmacol. 2002; 80: 37-42.

Johansen DA. Plant microtechnique. New York: McGraw Hill; 1940.

Krak K, Mráz P. Trichomes in the tribe Lactuceae (Asteraceae) - taxonomic implications. Biologia. 2008; 63(5): 616-630.

Kohler I, Jenett-Siems K, Siems K, Hernández MA, Ibarra RA, Berendsohn WG, et al. In vitro Antiplasmodial investigation of medicinal plants from El Salvador. Z. Naturforsch. 2002; 57: 277-278. 
Metcalfe CR, Chalk L. Anatomy of dicotyledons: leaves, stem, and woods in relation to taxonomy with notes on economic uses. Oxford: Clarendon Press; 1950.

Milan P, Hayashi AH, Appezzato-da-Glória B. Comparative leaf morphology and anatomy of three Asteraceae species. Braz Arch Biol Technol. 2006; 49(1): 135-144.

Nakagawa Y, Linuma M, Matsuura N, Yi K, Naoi M, Nakayama $\mathrm{T}$, et al. A potent apoptosis-inducing activity of a sesquiterpene lactone, arucanolide, in HL60 cells: a crucial role of apoptosis-inducing factor. J Pharmacol Sci. 2005; 97(2): 242-252.

Nascimento AM, Oliveira DCR, Albuquerque S. Evaluation of trypanocidal activity from Calea uniflora (Heliantheae-Asteraceae) extracts. Braz J Pharmacogn. 2002; 12: 49-50.

Nascimento AM, Salvador MJ, Candido RC, Itoc IY, Oliveira DCR. Antimicrobial activity of extracts and some compounds from Calea platylepis. Fitoterapia. 2004; 75: 514-519.

O'Brien TP, Feder N, McCully ME. Polychromatic staining of plant cell walls by toluidine blue $\mathrm{O}$. Protoplasma. 1965; 59(2): 368-373.

Oliveira AMA, Santos VLP, Franco CRC, Farago PV, Duarte MR, Budel JM. Comparative morphoanatomical study of Baccharis curitybensis Heering ex Malme and Baccharis spicata (Lam.) Baill. Lat Am J Pharm. 2011; 30: 1560-1566.

Pagni AM, Masini A. Morphology, distribution and histochemistry structures in vegetative organs of Santolina leucantha Bertol. (Asteraceae). Israel J Plant Sci. 1999; 49: 257-263.

Pereira C, Farago PV, Budel JM, De Paula JP, Folquitto DG, Miguel OG, et al. A New Contribution to the Pharmacognostic Study of Carquejas: Baccharis milleflora DC., Asteraceae. Lat Am J Pharm. 2014; 33(5): 841-847.

Ribeiro VL, Avancini C, Gonçalves K. Acaricidal activity of Calea serrata (Asteraceae) on Boophilus microplus and Rhipicephalus sanguineus, Vet Parasitol. 2008; 14(151): 351-354.

Ribeiro VL, Santos JC, Martins JR, Schripsema J, Siqueira IR, von Poser GL, et al. Acaricidal properties of the essential oil and precocene II obtained from Calea serrata (Asteraceae) on the cattle tick Rhipicephalus (Boophilus) microplus (Acari: Ixodidae). Vet Parasitol. 2011; 30(179): 195198.
Ribeiro VL, Vanzella C, Moysés FS, Santos JC, Martins JRS, von Poser GL, et al. Effect of Calea serrata Less $n$-hexane extract on acetylcholinesterase of larvae ticks and brain Wistar rats. Vet Parasitol. 2012; 26(189): 322-326.

Roeser KR. Die Nadel der SchwarzkieferMassenprodukt und Kunstwerk der Natur. Mikrokosmos. 1962; 61(2): 33-36.

Roque N, Carvalho VC. Taxonomic studies of the genus Calea (Asteraceae, Neurolaeneae) in Bahia state, Brazil. Rodriguesia. 2011; 62(3): 547-561.

Sass JE. Botanical microtechnique. 2. ed. Ames: Iowa State College; 1951.

Souza CA, Farago PV, Duarte MR, Budel JM. Pharmacobotanical study of Baccharis singularis (Vell.) G.M. Barroso, Asteraceae. Lat Am J Pharm. 2011; 30: 311-317.

Souza JP, Santos VLP, Franco CRC, Bortolozo EAFQ, Farago PV, Matzenbacher NI, et al. Baccharis rufescens Spreng. var. tenuifolia (DC.) Baker: contribuição ao estudo farmacognóstico. Rev Bras Plantas Med. 2013; 15(4): 566-574.

Tavares ES, Nascimento LBS, Moreira NS, et al. Foliar morpho-anatomical characterization of medicinal plant Youngia japonica (L.) D.C. (Asteraceae). Planta Med. 2012; 78-PL4.

Yamada M, Matsuura N, Suzuki H, Kurosaka C, Hasegawa N, Ubukata M, et al. Germacranolides from Calea urticifolia. Phytochem. 2004; 65(23): 3107-3111.

Youssef J, Döll-Boscardin PM, Farago PV, Duarte MR, Budel JM. Gochnatia polymorpha: macro- and microscopic identification of leaf and stem for pharmacognostic quality control. Braz J Pharmacogn. 2013; 23(4): 585-591.

Werker E. Trichome diversity and development. Plant trichomes (D.L. Hallahan, J.C. Gray). London: Academic; 2000.

Wu H, Fronczek FR, Burandt CL, Zjawiony JK. Antileishmanial Germacranolides from Calea zacatechichi. Planta Med. 2011; 77(7): 749-753.

Received: August 31, 2013; Accepted: June 26, 2014. 